\title{
A Critical Analysis of Cashless Banking Policy in Nigeria.
}

\author{
${ }^{1}$ Ezuwore- Obodoekwe C. N, ${ }^{2}$ Eyisi A.S, ${ }^{3}$ Emengini S.E, \\ ${ }^{4}$ Alio Felix Chukwubuzo \\ ${ }^{1,2,3,4}$ Faculty Of Business Administration, Departments Of Accountancy \&Banking/Finance, University Of \\ Nigeria, Enugu Campus.
}

\begin{abstract}
This paper analyses critically to the very beginning, the introduction of cashless policy in banking business in Nigeria. The cashless system has become necessary to promote the use of electronic means of transaction towards making Nigeria a cashless economy in the nearest future, where clumsy and expensive-tohandle coins and notes are replaced by efficient electronic payments system. It discusses how the new policy directs banks to cease cash-in-transit lodgment services hitherto rendered to merchant customers. The banks are to engage the services of the Central Bank of Nigeria (CBN) licensed cash-in-transit ( CIT) companies to aid cash movements to and from their banks at mutually agreed terms. The CBN has stipulated appropriate sanction against banks that flout the ban on cash-in-transit lodgment services.
\end{abstract}

Keywords: Cashless, Banking \& Policy Of Cashless Banking,

\section{Introduction}

Banks are the cornerstone of an economy. It is the engine house for societal and economic development. The importance of banking services to the growth and development of any economy cannot be over- emphasized.

The most significant development of the millennium which has substantially influenced business operation in the world today is the emergence of the information age. The remarkable progress achieved in information and Communication Technology (ICT) has made its possible for the information to be digitalized and also transmitted faster and even cheaper in mega and tetra bytes. Taking advantage of this rapid technological progress and financial market development, a number of innovative products for making transactions have been developed in recent years, these transactions involve the transfer of monetary value from one person to another. Thus, a transaction consists of mechanisms which include institutions, people, rules and environment that make exchange possible.

However, transaction made using these innovative products are accounting for an increasing proportion of the volume and values of domestic and cross border retails transaction. Currency and notes are converted into data which are transmitted through telephone lines and satellite transporters (Ovia 2002). These new financial services through electronic medium have caused substantial reduction in transaction costs and ease of transfer of funds.

Prior to the advent of this electronic devices in the delivery of banking services in Nigeria, banking operations were marred with ineptitude, time consuming bureaucratic, bottleneck, long queues, crowd and such like complaints from the public. As a result of all these, the psychology or mental picture of the average individual towards banking services has been negatively affected. Some individual seems to prefer to keep their money to themselves or put it in to use anywhere else but not the bank. They prefer to do so as they always encounter one problem or the other whenever they go to withdraw money at the bank. Moreover banks generally develop large amount of data in the course of their operations. The collection, storage and management of these data are no doubt a very daunting task. The manual approach of these bank services and management was characterized by long queues, tally numbering, stress, loss of valuable works hour, and so on.

\section{The Policy Of Cashless Banking In Nigeria}

The need to improve or if possible eliminate all Problems of long queues, tally numbering, stress, loss of valuable works hour, in the delivery of bank services led to the quest for Electronic banking which is a product of a cashless policy which in its usage and application would help to reduce the cost of primary money, that is the rate of money circulation and also help to detect and prevent fraud in the financial system.

According to the CBN, the cashless policy has become necessary to promote the use of electronic means of transaction towards making Nigeria a cashless economy in the nearest future. CBN says the policy is in reaction to the increasing dominance of cash in the economy with its attendant implications for cost of cash management to the banking industry, security, money laundering, among other huge cost. The policy was endorsed by the Bankers Committee, which comprises the CBN, the Nigeria Deposit Insurance Corporation (NDIC), Discount Houses and the 24 commercial banks in the country.( DAILY SUN OF JANUARY 04, 2012 COMMENT). 
Under the policy, effective from June 1, 2012 daily cumulative withdrawals and lodgment in banks by individual would be limited to a maximum of $\$ 150,000$, while daily cumulative withdrawals and lodgments by corporate customers is pegged at $\$ 1$ million. However, individuals and corporate organizations wishing to withdraw above the fixed amount would have to pay special charges. Such special charges are not yet clear. In recent times, the bankers committee meeting has become a forum where the Central Bank of Nigeria, $(\mathrm{CBN})$, unveils its monetary policies, especially those affecting the banking sector. It was at that forum that Sanusi Lamido Sanusi, governor of CBN, announced the sacking of chief executives of eight banks that were pronounced technically distressed. It was therefore, not surprising that Sanusi chose the April 28, monthly meeting of the bankers' committee to announce new guideline on cash withdraws from banks.

The guidelines spell out sanction for individuals and companies that flout the new cash policy. For individuals that make cash transactions above the daily limit, they would be surcharged $\$ 100$ per every $\$ 1000$ while the penalty for a corporate organization that exceeds the one million daily withdrawal limit is pegged at $\$ 200$ per every $¥ 1000$.

In a circular dated 20th April, 2011 and addressed to all Banks; CIT Companies; Payments System Service Providers Switches; Card Acquirers, Issuers and Processors, the apex bank wrote "in view of increasing dominance of cash in the economy with its implication for cost of cash management to the banking industry, security, money laundering, etc., the Central Bank of Nigeria, in collaboration with the Bankers Committee, is adopting policies to reduce the high usage of cash, moderate the cost of cash management and encourage the use of electronic payment channels."

The circular, which was signed by Muhammad Nda, Director, Currency Operations Department read: "Consequently, the Central Bank of Nigeria hereby directs as follows:

1). Commencing from June 1, 2012, a daily cumulative limit of N150,000 and N1,000,000 on free cash withdrawals and lodgements by individual and corporate customers respectively with Deposit Money Banks (DMBs) shall be imposed. To this end, individuals and corporate organizations that make cash transactions above the limits will be charged a penal fee of N100/thousand and N200/thousand respectively for amounts above the cumulative limits.

2.) Contravention of this policy shall attract a fine of five (5) times the amount that the bank waives as a first offender. Subsequently, the bank shall pay ten (10) times the charges waived.

3 ) Furthermore, 3rd party cheques above N150, 000 shall not be eligible for encashment over the counter. Value for such cheques shall be received through the clearing house. If a bank allows 3rd party cheque encashment, it shall be liable to a sanction of $10 \%$ of the face value of the cheque or N100,000 whichever is higher.

4 ) Banks will cease cash in transit lodgement services rendered to merchant-customers from June 1, 2012. In this regard, customers could engage the services of the CBN licensed cash-in-transit (CIT) companies to aid cash movement to and from their banks at mutually agreed terms and conditions. Contravention of this policy shall attract a fine of N1.0 million per specie movement.

5) This arrangement shall be in force in Lagos state, F.C.T., Port Harcourt, Kano and Aba in the first instance. The arrangement shall be extended to other parts of the country at a date to be determined by the Bankers Committee.

6). To achieve interoperability of local currency POS transactions, no card scheme, foreign or local, shall operate exclusive acquirer agreement or contract in Nigeria with effect from June 1, 2011. Any payments scheme, processor, switching company, service provider or bank that contravenes this policy may be suspended for a minimum of one (1) month by the $\mathrm{CBN}$ as a processor, switching company, service provider etc in the first instance. The license may be withdrawn by the $\mathrm{CBN}$ if the contravention is repeated.

7) This policy shall apply to both private and public sector transactions. All financial institutions including Deposit Money Banks, Savings and Loans, Mortgage and Microfinance Banks shall comply accordingly.

8) Compliance with the policy shall be monitored by the Banking Supervision Department and the Other Financial Institutions Supervision Department with appropriate sanction applied to erring institutions."

It concluded by saying that, "While the Central Bank of Nigeria will make general announcements and carry out public awareness programmes individual banks are expected to do same. The affected customers of banks should be informed in good time by the banks with clear advice on alternative electronic payment channels available to them."

\section{The Operational Mechanisms Of Cashless Banking}

* What is a Cashless Policy?

A cashless society is a society where no one uses cash, all purchases being made by credit cards, charge cards, cheques or direct transfer from one account to another. Or it is a policy that minimizes the use of cash by providing alternative channels for executing financial transactions. 
It can also be the ability to store money in an electronic purse or Card which is fast becoming standard practice throughout the workplace. The electronic purse is then used to purchase products within the business premises.(http/www.Investorwords. com/11137 society html.-accessed on 28/03/13)

\section{* How does it work?}

Users are issued with a card. The electronic purse is topped up using revaluation terminals. A range of terminals are now available including coin \& note, credit card or payroll deduction terminal. Simply by inserting the card into a revaluation terminal and following the instructions given, money is added onto the electronic purse on the card. The card then replaces your wallet or purse when paying for goods at both vending and catering facilities. Card readers are installed at all Points of Sale (e.g. vending machines, restaurant tills, coffee bar till, staff shops). Instead of juggling with cash at the Point of Sale, the card is inserted into the reader and the total sum of the purchase is quickly and accurately deducted from the card.

\section{* Why the Cash Policy?}

The new cash policy was introduced for a number of key reasons, including:

1. To drive development and modernization of our payment system in line with Nigeria's vision 2020 goal of being amongst the top 20 economies by the year 2020. An efficient and modern payment system is positively correlated with economic development, and is a key enabler for economic growth.

2. To reduce the cost of banking services (including cost of credit) and drive financial inclusion by providing more efficient transaction options and greater reach.

3. To improve the effectiveness of monetary policy in managing inflation and driving economic growth. In addition, the cash policy aims to curb some of the negative consequences associated with the high usage of physical cash in the economy, including:

- $\quad$ High cost of cash: There is a high cost of cash along the value chain - from the CBN \& the banks, to corporations and traders; everyone bears the high costs associated with volume cash handling.

- High risk of using cash: Cash encourages robberies and other cash-related crimes. It also can lead to financial loss in the case of fire and flooding incidents.

- High subsidy: CBN analysis showed that only 10percent of daily banking transactions are above 150k, but the 10percent account for majority of the high value transactions. This suggests that the entire banking population subsidizes the costs that the tiny minority, this suggests that the entire banking population subsidizes the costs that the tiny minority 10percent incur in terms of high cash usage.

- Informal Economy: High cash usage results in a lot of money outside the formal economy, thus limiting the effectiveness of monetary policy in managing inflation and encouraging economic growth.

- Inefficiency \& Corruption: High cash usage enables corruption, leakages and money laundering, amongst other cash-related fraudulent activities.

* Content of the Cash policy

The following aspects of the policy shall apply from January 1st 2012 in Lagos State ("tagged Cash-less Lagos"):

- $\quad$ Only CIT licensed companies shall be allowed to provide cash pick-up services. Banks will cease cash in transit lodgment services rendered to merchant-customers in Lagos State from December 31st 2011. Any Bank that continues to offer cash in transit lodgment services to merchants shall be sanctioned.

- $\quad 3 r d$ party cheques above N150, 000 shall not be eligible for encashment over the counter. Value for such cheques shall be received through the clearing house.

Informal Economy: High cash usage results in a lot of money outside the formal economy, thus limiting the effectiveness of monetary policy in managing inflation and encouraging economic growth.

Inefficiency and Corruption: High cash usage enables corruption, leakages and money laundering, amongst other cash- related fraudulent activities.

\section{* Expected Benefit of the Cashless Policy:}

Benefits of Cashless Economy A cashless economy or an e-payment system is a situation where there is little or very low cash flow in a given society, thus every other purchases and transactions will be made by electronic channels, examples of which are direct debit, electronic funds transfer, mobile payments, multifunctional ATMs, internet banking and a significant increase in point of sale (POS) penetration and usage. In other words, it simply refers to the widespread application of computer technology in the financial system. Payments under this new system will range from a list of options such as cheques, wire transfers, debit and credit cards, online transactions, and mobile banking. The advantages of a cashless society are enormous; from regulating, controlling, and securing the financial system of any economy 
A variety of benefits are expected to be derived by various stakeholders from an increased of utilization of e- payment systems: These include

(i) For Consumers: Increased convenience; more service options, reduced risk of cash- related crimes; cheaper access to (out of branch) banking service and access to credit.

(ii) For Corporations: Faster access to capital; reduced revenue leakage; and reduced cash handling costs.

(iii) For Government: Increased tax collections, greater financial inclusion; increased economic development.

(Boughton and Wicker, 1975; Austrement 2007).

\section{* What are other benefits?}

Other benefits as identified by Obiora Aduba are as follows:

\section{Faster transactions}

It has been proven time after time that queuing at point of sale terminals and vending machines is greatly reduced; typically three times more people can be served using a cashless system than could have been if they were paying cash. This leaves employees more time to enjoy their break and encourages them to come back to the restaurant. Improving the speed of service may also offer the benefit of reducing staff levels at off peak times.

\section{Improves hygiene on site}

The handling of coins and notes provides an easy way for bacteria to spread quickly from one individual to another. A recent study of coins and notes revealed the presence of bacteria on $87 \%$ of the notes!! With a cashless system, the catering staff no longer have to handle cash, at the same time as serving food.

\section{$>\quad$ Managing staff entitlements}

Free Vends, corporate cash, loyalty and hospitality spend are all entitlements which can be programmed on to the card, this can be refreshed, daily, weekly or monthly, whilst the cards can be configured so that any unused allowance is lost or accumulated, dependent on the client's requirements.

In some instances it may be necessary to charge different tariffs for visitors and staff, the VMC Metro system manages tariffs and entitlements automatically.

\section{$>\quad$ Increased Sales}

It has been demonstrated that with the introduction of a Visa Master Care ( VMC) cashless system can increase sales by as much $20 \%$.

Vending and Catering purchases are often dictated by the amount of loose change we have in our pockets. With the introduction of a cashless system this is never a problem, the value on the card is available 24 hours a day, 7 days a week.

$70 \%$ of vending machine faults are coin related! Often vending machines require the exact change to be inserted in order to make a purchase. This can be frustrating and many times, people decide not to bother. Removing coins from your machines improves reliability, and overcomes the exact change problem. All this adds up to more sales and happier customers.

\section{$>\quad$ Cash collection - made simple!}

Time spent collecting, counting and sorting cash costs money. The VMC cashless system offers a choice of top-up options including Payroll deduction, Credit \& Debit card and Coin \& Note.

Removing all the cash from your site removes the security issues relating to cash handling significantly and reduces the risk of vandalism and theft from your vending and catering points of sale.

\section{Guests}

When a guest arrives at an office how do they buy lunch? Simple.... As well as the revaluation terminals already installed on site, it is possible to install guest or visitor card terminals, providing 24 hour card dispensing facilities. Cards returned to the terminal are collected and any remaining balances are refunded. The terminal can also manage a card deposit to provide an incentive to return the card.

\section{Simple Solutions}

A cashless system from VMC provides a wide range of benefits which ensure a smooth running operation for businesses both big and small. 
However, there is literature substantiating the emergence of a cashless economy, where paper money (which happens to be legal tender in many economy is replaced with electronic money which is facilitated with the advances in technology - as witnessed in the invention of the of internet, the development of electronic account systems and the increasing sophistication in major industries all around the world - and hence paper money becomes functionally deficit as its functions would be reduced potentially, and drastically, although not completely in true sense to just a mere unit of account!

Electronic money and hence the introduction of the cashless economy is one that has been discussed in literature as found in the Wicksell's $(1898,1935)$ pure credit economy where 'monetary policy (is conceived) without money' (Bionovsky and Trautwein 2004). These studies considered the case of the cashless economy and the connection between the flows of investor demand as measured by movements in the demand deposits and the real sector and this is further witnessed in Wood ford, (1997); Good friend and King, (1997) and Berg et al, (2006) who suggest that money does not really matter in the determination of price movements and hence inflation and therefore the economy can do without cash as the money is not relevant for manipulations in the price level while the quantity theorists claims otherwise. Away from the monetary policy implications of the introduction of a economy some authors have investigated the introduction of electronic money with a view to ascertaining its implications for transaction, regulations, cost to banking and non bank public (Good, 1997; Godshalk and Krueger, 2000; Palley, 2001; Rogers 2004).

However, most of these studies centred on the comparatively more advanced countries of the world which were the likely candidates for the so called e- revolution given the standard of living, the peculiarity of their monetary policy issues and the technological sophistication. With the development of sophisticated forms of money also develops sophisticated forms of financial crimes both at the public and private sectors (Woda, 2006; financial action task force, 2010).

Literature on e- money and cashless banking is one that is quite scanty in less developed countries as this may not be unconnected to the heavy presence of the informal sector in most dual developing economies and the poor banking culture in the same. Hence against this backdrop there is the need to investigate the introduction of e- money in developing countries - like their developed counter parts - and the likely consequences of once again adopting a sophisticated financial model that makes the rounds in developed countries.

The service charges/fees did not apply until March 30th, 2012, in order to give people time to migrate to electronic channels and experience the infrastructure that has been put in place. Therefore, banks should continue to encourage their customers to migrate to available electronic channels, and where possible demonstrate the costs that will accrue to those that continue to transact high volumes of cash from March 30th, 2012 in Lagos State.

In addition, below are some detailed context and pertinent clarifications on the policy:

\section{- Location}

- The pilot shall be run in Lagos State.

\section{- Account Application}

- The cash-policy applies to all accounts, including COLLECTION accounts. Banks should therefore work with their corporate customers to arrange for suitable e-collection options.

o

- $\quad$ Limits

- The limits are cumulative daily limits each for withdrawal, and for deposits (e.g. for Individuals, the daily free withdrawal limit is N500,000; while the daily free deposit limit is N500,000)

- The limits apply to the account so far as it involves cash, irrespective of channel (e.g. over the counter, ATM, 3rd party cheques encashed over the counter, etc) in which cash is withdrawn or deposited (e.g. if an individual withdraws $\mathrm{N} 450,000$ over the counter, and N150,000 from the ATM on the same day, the total amount withdrawn by the customer is N600,000, and the service charge will apply on N100,000 - the amount above the daily free limit). The limit also applies to cash brought through CIT companies, as the CIT company only serves as a means of transportation.

\section{- $\quad$ Charges}

- The charges shall apply from March 30th 2012 in Lagos.

- The service charge for daily cumulative deposits above the limit into an account shall be borne by the account holder. However, during the pilot in Lagos, individuals paying money from Lagos, into an account outside Lagos, shall bear the charges for any single transaction above the daily limit. 
- The service charge for daily withdrawals above the limit into an account shall be borne by the account holder.

\section{- Interstate Transactions}

- Charges/fees shall apply for all transactions in Lagos, and on Lagos State based accounts.

- Transactions initiated out of Lagos State, and affecting a Lagos based account shall not attract charges/fees, and shall not be counted as part of the daily cumulative amount on that account since the policy has not been activated outside Lagos. (E.g. A deposit above the limit made from Onitsha into a Lagos state account shall not attract charges/fees).

- Transactions initiated from Lagos State, and affecting an account outside Lagos, shall attract charges/fees (when the specific transaction is above the limit), since the policy has been activated in Lagos. (E.g. A deposit made from Lagos State above the limit, into an account in Abuja, shall result in the initiator paying the relevant charges/fees, while the account into which it is paid outside Lagos shall not be impacted).

The policy will eventually be rolled out to other regions across the country from January 1st 2013. Please note that the policy does not prohibit withdrawals or deposits above the stipulated amounts, but that such transactions will be subject to cash handling charge.

\section{Modeling Cashless Banking in a Developing Economy}

"Developing countries", are plagued with the feature of the existence of a dual economy which is an economic situation where there is an existence of the formal sector with its crude solutions to modern day problems as noted in Nafziger, (2006), however, these different sections of the economy are serviced by the very same financial system which has undergone reforms in line with the realities of the global financial system, as noted in Nigeria, the case being studied here. Therefore, there is the need to discover the implications of the introduction of the financial innovation e- money in an economic system that is composite of the informal and formal sectors.

\section{An Overview of Nigerian Experience in Respect to the Development of E- Banking}

The world, as noted by Roger (2000), has become a virtual global village with the array of development going in the information technology super highway. Many banks in Nigeria are in recent times embracing e- banking especially since it is believed that it drives down their cost and increase customers' services.

In the 1980's, the processing of information in banks in Nigeria was based on the centralized architecture with a main frame computer running a multi-user operating system and various users connected to it via terminals. This type of processing later changed to a more decentralized approach with a Local Area Network(LAN) within bank branches. Recently, the application of modern technology has affected all aspects of the nation's banking industry from the standard retail operations such a withdrawal and cheque processing to creation and delivery of sophisticated corporate products such as foreign exchange swaps.

The electronic revolution in Nigerian banking sector started sometime in the early 1990's. However, the first visible form of electronic innovation in the nation's banking industry was the introduction of ATM in the early 1980's by a commercial bank in the country. Some other bank followed, but the product was not well received by the banking community and this no doubt curtailed its spread in the early 198 's.

Another application of electronic innovation apart from the ATM is the Smart Cards in Nigeria commenced in the late 1990's when the Central Bank of Nigeria granted an approval to a bank in the country in 1996 to introduce a financial product (a closed system electronic purse) known as the Electronic Smart Card Account (FSCA). The pioneering efforts of this bank were followed in 1997 with the introduction of a pay- card by another bank in the system. In 1998, the CBN gave an approval to a company floated by a consortium of 19 licensed banks to produce and manage card issued by member banks.

Apart from Veering into Electronic Fund Transfer (EFT), the society for world- wide Inter- bank financial Telecommunication. (SWIFT), which some Nigerian banks have acquired membership has no doubt facilitated inter-bank transactions.

\section{Electronic Banking}

Electronic banking is an aspect of electronic commerce (e-commerce) and it is derived from the success recorded in IT.

Electronic banking is the provision of banking service by financial institutions to their customer via electronic devices. As a paperless method of banking, e-banking offers an alternative to the traditional systems which rely on physical presence and involve the use of cheques. E- Banking is the totality of the deployment of 
modern IT and communication systems to record financial transactions as well as deliver financial services to the customer.

The system has the advantage of enabling transactions to be processed quickly and offer a much more convenient method of effecting financial transactions. The major reason for the involvement of most banks in electronic banking is to improve business processes, reduce transaction costs and enhance their overall service delivery efficiency.

Electronic Fund Transfer (EFT), the major aspect of electronic banking is simply the use of electronic means to transfer funds from one account to another rather than by cheque or cash. Electronic banking is sometimes called EFT due to their similarities in function.

S. M. Nzoha (2004) has it that these e-banking and EFT depend on electronic

Signals communicated through satellite or microwave links. They work to enhance the efficiency and productivity of banks.

\section{- $\quad$ The Facets of E-Banking}

The forms of this paperless banking system include:

(i) Automated Teller Machine (ATM)

(ii) Point of Sale (pos) terminal

(iii) $\quad \mathrm{PC}$ (home/ office) Banking

(iv) Mobile banking

(v) Electronic currency

(vi) Electronic commerce (e- commerce)

\section{The Automated Teller Machine (ATM)}

According to Collins Uweribe and Olowah Peter (business Day, April 2008), beside the Fax machine telephone, internet, GSM, one other invention by man that has changed' the modern day banking in recent time is the electronic software and hardware solutions configured to enable payment easier and faster either at a banks, sales off- site locations or other electronic channels of delivery.

For Nigerian the deployment of Automated Teller Machines, ATMs, in 2006 by Nigerian banks was one of the benefits of the banking sector consolidation exercise. It revolutionized the payment system in the economy and relieved businessmen of the burden of carrying cash. ATMs also offered them convenient access to their deposits at any hour of the day. More so, the widespread location of ATMs in churches, bars, hotels, markets, school, hospitals, filling stations and street of Nigeria major cities further enhanced this convenience.

But recently, the revolution that puts smiles on many faces is becoming a major sources of concern and sorrow for users. Internet fraudsters are using the ATMs to rip off large sums of money from depositors. Currently, many of them have stories of woe to tell. One of the victims is olayinka Ayanniran, a customer of oceanic bank International Plc. He lost one million naira to fraudsters in four withdrawals that occurred between January 15 and 20, 2009

The concept of Automated Teller Machine (ATM) as known today first began in 1968. A working prototype came about it in 1869 and Docitel, an American Company, was issued a patent in 1973. It is believed that Don Wetzel a copatentee conceptualized the idea while writing in line in a Dallas bank. At a time, he was the Vice President of product planning at Docitel. The first working ATM was therefore, installed in a New York based bank in 1969 and it was regarded as the first modern day ATM. The bank introduced ATM to customers the same year. After forty (40) years of the introduction of ATM, Nigeria joined the developed world in its use fully in 2005 through the tireless efforts of the CBN in collaboration with the bankers committee.

According to Weiner (1999), an ATM card allows a customer to withdraw cash from his bank account by entering a personal identification number (PIN) and having the amount of the withdrawal immediately debited to his account. The ATM's were introduced in the retail banks with object of reducing personal costs associated with the traditional "teller window" customer service transaction. Transactions in ATM's rely on an extensive communication system that includes network that can interact with one another. The machines to a large extent relieve banks from the constraints of time and geographical location. They present banks with a more commercial substitute for "brick and mortar" (traditional banking system or Institution that does not offer internet banking services) branches.

\section{Electronic Commerce}

Imagine being able to pay for cloth, home wares, lap-top, books tuition, and subscription, even 'international with just' a click on the net. Imagine you are at a location where you need to make a urgent call but there is no recharge card vendor around you, or you are traveling but you need to transfer money to someone urgently. How do you do all these? That brings us to the subject of e-commerce. 
The internet has changed, the why an access, use and communicate information. It's continuing growth and, evolution has transformed the why consumers transact and interact with providers of goods and services. We are witnessing the birth of electronic commerce..." He said E-commerce is like a virtual market that is expected to be generating around $\$ 500$ billion transactions in 5 years to come. With its growth rate at present, sooner or later everybody will be connected to the virtual market, e- commerce. Therefore, every forward looking organization must recognize this market as a new delivery channel and start packaging and designing services through it. Banking as mentioned earlier and indeed commerce of this day are done in the comfort of homes and offices with a personal computer wired to the world wide network.

\section{Mobile Banking}

Margaret Johnson in her journal (business day April/June 2005 ), says following the launching of Global System Mobile (GSM) services in Nigeria in 2001, few banks in Nigeria have launched the mobile banking services that enable customers carry out simple transactions based on SMS with customers mobile phone serving as the terminals. Such transaction include: account balance enquiries, fund transfer between the customers own account and other accounts with the same banks transactions involving the third party payment such as payment of bills, cheque book requests, balance confirmation, purchase of recharge cards, statement of account, etc. As at 2006, over 10 banks have offered mobile banking services. The security controls used here is PIN code and pass code identification.

The telephone banking services offers customers access to their account as well as allow them carry out their banking transactions at their convenience through a GSM phone from any service location worldwide. There is an alert service which provides customers instant Notification on your mobile with respect to any transaction which happened on your account. This alert service also offers customers the benefit of convenience, quick service and reduction in financial cost of banking transaction.

\section{Security aspect of Cashless Banking (E-Banking.)}

Nzoha(2004), has quoted thus that electronic fraud has become a global problem and phenomenon. Electronic fraud has increased tremendously in Nigeria; especially giving the complexities of the system. He continued by saying this poses a lot of threat to the efficient operation of e- banking.

Ezeoche Ighile a business day journalist from an interview on the streets of Lagos gathered that security measures at the cash points are very loose. The cash points are not safe and information like your PIN is not secure. Ogonna Maduka, a resident of Independence Layout, Enugu, said concerning security issue that it is not safe to use the ATM machine around her residence as some so called "Smart boys" could empty your account or even harass you physically. Some respondents were of the view that a lot can still be done in terms of security at cash points. An anonymous respondent said: I cannot use the ATM at night; the place is poorly lit.

Ola to Kunbo Koleye (business day, April 2008) says the number one security concern of e- banking is fraud. According to Collins Uweribe and Olowa peter, the growth in ATM has been highly beneficial to both bank management and the household alike, but it has brought about a weak point system by creating a precise condition in which organized criminals carry out fraud. The problem of fraud in Nigerian is phenomenal because of the active connivance of bank officials. It was gathered that some bank staffs have been involved in this fraud by feeding the criminals, as a result of the technique advance through which they obtained card PIN numbers and the sensitive data held in magnetic strips. Criminals place false fascia containing magnetic strips readers on the front of genuine ATM to collect informations and also install mini-cam masquerading as security cameras in order to record PIN number as they are entered on the ATM levy pads. Using this technique they are able to fraudulently withdraw large amounts of amount of cash. In doing so, they fraudsters are striking at the very core of an individual. Measures need to be set in place to deal with these card fraud and other electronic banking problems. There are also computer hankers, who break in to a bank's computer system. They are computer wizards who breaks through passwords and locks in the banks computer system, making manufacturing and alteration to south their fraudulent desire. In the late 1980' and early 1990's Europeans institutions experience similar problems and was able to overcome them using different fraud detections measures.

\section{Mature To Detect And Curb E-Banking Frauds:}

Collins and Olowa stated that European institutions experienced similar fraud problems and were able to organize them using different fraud detection solutions such as the neural network solution and Alaric Bayesian solution. The two measures have their probability theories. The Bayesian probability works effectively with much smaller sample and provides equal, if not better results than the neutral network solution. Alaric's Bayesian method essentially involved counting the occurrence of fraudulent transactions and calculating the frequency with which they occur. Card fraud is an ongoing issue and because of this, there is no fixed solution. 
It is therefore the responsibility of the banking industries to continually set measures in place to detect the changing nature of card misuse (Collins and Olowa).

ADAYECH'S report in business Day (2008) has it that the security of ATM transactions ( and other ebanking services) rely mostly on the integrity of secure crypto-processor but despite sophisticated encryption of PIN, ATMs are still susceptible to card fraud. Verifying card however, identifying and authentically transaction however, need no longer remain a major problem with the introduction of the Aixs brand of Biometric ATM's in Nigerian. These ADAETICH's based on authorization of transactions on either scanning of a customer's finger prints, facial recognition or voice. No need for bank customers to carry card or even keep PIN. This not only minimizes the usually card security risk, but also offers a great convenience to customer why generating a high level of security.

CBN in its existing framework has issues guidelines to also cover the issuance of electronic money by banks in Nigerian. However, the distinctive of characteristics of the new technology is requires some new thinking and rules. All involved in e-banking must try to maintain adequate and reliable safeguards in order to present, protect and detect any possible threat to the security and integrity of scheme including the threat of counterfeit as well as unauthorized access or modification.

It is in this regard that CBN warned that all banks offering that ATM services and other Electronic banking services would be held accountable for case of fraud. In the guidelines of electronic banking in Nigeria sent to bank by the CBN, banks will be considered liable for fraud arising from card skimming, counter filtering and internet hacking ( CBN bulleting 2003 p.g 3) worried about what the loss would be to the customer and the banking system, the CBN further directed that the : in view of demonstrating weakness in the magnetic strip technology, banks should adopt the chip /smart card and technology".

To further ensure effective security of the customer as well as the scheme, central bank of Nigerian has directed that:

(i) bank are encourage to instill cameras at ATM locations.

(ii) All ATM not located within the bank premises must be situated in a manner to ensure safety to customer using them.

(iii) Appropriate lighting most be available at all times and mirrors may be placed around the ATM to enable the individual using the ATM to determine the movement of persons in the immediate Vicinity.

\section{Prospect Of Cashlees Banking (E-Banking)In Nigeria}

Electronic banking is becoming increasingly important in Nigerian because of the increasing competitions from non-bank financial institution and the demand for more efficient and convenient services in the competitive environment brought about by the deregulation coupled with the recent adoption of universal banking, technology seems now to be the single biggest strategic issue in banks. Several banks has realized the immense benefit of IT as a tool for bringing their products and services to the convenience and reach of their customers and also as a means of increasing their productivity.

Although there are challenges but in view of some recent developments in the country there are reasonable prospects for the development of e-banking in Nigeria. Some of the developments include:-

The regulatory authorities require that all approved issues of e-money (smart cards, smart pays, etc) should enter into contractual agreement with the Nigerian Inter-Bank Settlement System (NIBSS) for the clearing as well as settlement of e-money products.

The ongoing effort by the present administration to bring about an improvement in the state of the nation's infrastructural facilities both in the energy and the communication sectors of the economy. For example, the ongoing revolution in the nation's telecommunication sector especially the efforts to privatize NITEL, the Licensing of the GSM operators and the coming on-stream of many other private firms now operating within the nation's communication sector, will go a long way to engender the development of ebanking in the country.

The setting up of a committee on e-banking by the regulatory/supervisory authorities to design an appropriate policy framework for the effective regulation of e-banking in Nigeria. The committee is expected to review all existing legal framework and see how it affects e-banking, identify specific risks, measure consumer's standard, identify the effect on monetary policy effectiveness and to have IT standards. The setting up of the committee on - e-banking was necessitated by the urgent need to start building robust regulatory and supervising capacity that will nurture and promote the growth of e-banking in Nigeria. The continued efforts at improving the corporate governance of banks, especially the continued encouragement of banks by the regulatory/supervisory authorities of the need to always adopt good employment policy which will guarantee that staffs recruited are people of impeccable character integrity and high moral probability. The continued and constant upgrading of the supervising capacity of regulatory / supervising authorities in IT and skills in acceptable standard through continuous training and development of staff. These efforts, designed to ensure that all bank examiners are IT literate, is to enable them achieve competence and necessary skills in auditing through 
computer-based system so as to create the desired framework for e-banking surveillance. The constant monitoring and attention of the authorities to money laundering Act which require financial institutions to disclose to regulators/supervisors and the National Drug Law Enforcement Agency (NDLEA) any single transaction lodgment or transfer of funds in excess of N1,000,000. The release of guidelines by the authorities to banks intending to introduce e-banking products and more importantly, the recent "Know your customer" (KYC) directions to all bank and other financial institutions in Nigeria. The "KYC" directive, for example, was designed to ensure that banks put in place adequate policies practices and procedures that will allow for vigorous customers due for diligence check. The new directives was, among other things, meant to ensure the effective customer identification procedures and monitoring standards for telephone and electronic banking customers and proactively assess varying issues posed by emerging techniques.

\section{Methodology}

The research aimed at understanding how government policies could influence banking businesses through the Application of Effective cashless banking i.e. e-banking. What factors are critical to the Effective Application of the cashless banking?

After considering the problems and objectives of the study, survey design was chosen, because it would provide answers to questions, such as who, what, where, when, why and how as they are related to the government policies on banking performance with respect to cashless banking in Nigeria. Typically, answers to these questions are found in secondary and by conducting surveys. Therefore, two major sources were employed in the quest to gather information for the study. They were both secondary and primary sources.

Published and unpublished data were used. Published data were sourced from various publication of the Federal State and Local Government; various publications of foreign governments, international bodies, and their subsidiary organizations; technical and trade journals; books, magazines and newspapers; reports, and publications of various associations, $\mathrm{CBN}$ bullions, reports published by $\mathrm{CBN}$ and research scholars of related topics unpublished data were found in diaries, letters, unpublished biographies and autobiographies and labour bureaus.

Structured questionnaire was used to source the primary data; the researcher followed a sequence of logical steps to develop a good questionnaire that would accomplish the research objective. Questions were formulated to obtain the needed information; the questionnaire was scrutinized in order to prove it validity and meeting the required standard, in view of this, it was overhauled by four (4) senior lecturers of the University of Nigeria for omissions and ambiguity.

The population of the study was made up of the commercial banks in operation in Nigeria. The population was further narrowed down to an accessible population due to factors that might inhibit the success of the search objective. On the foregoing the population was now the commercial banks in operation in Enugu Metropolis, Enugu State: Access Bank, Nig. Plc, Union Bank of Nig. Plc, United Bank for Africa (UBA), Zenith Bank Plc, First Bank of Nig. Plc, Diamond Bank Plc, Ecobank Nig. Plc, Keystone Bank Plc, Fidelity Bank Plc, First City Monument Bank Plc, Guaranty Trust Bank Plc, Wema Bank Plc, Finbank Plc, Stambic IBTC Bank Plc. These are the commercial banks (fourteen) 14 in Enugu Metropolis.

Having known the population size, the sample size will be determined by using the Yaro Yamani; given the formula:

$=\mathrm{n} \quad=\frac{\mathrm{N}}{1+\left(\mathrm{Ne}^{2}\right)}$

$\begin{array}{lll}\text { Where } & & \\ \mathrm{n} & = & \text { the population size i.e. } 14 \\ \mathrm{I} & = & \text { is constant } \\ \mathrm{e} & = & \text { is the tolerable error i.e. } 0.05 \\ \mathrm{n} & = & \frac{14}{1+(14 \times 0.0025)} \\ & = & \frac{14}{1.035} \\ \mathrm{n} & = & 13.52 \\ \approx & 14 & \end{array}$

Having determined our sample size of the above mentioned commercial banks, then a structured questionnaire was designed to be administered amongst the senior bank staff of the banks under study.

A random sampling technique was used in administering the questionnaire, since each has the chance of occurrence or to be selected.

Out of the eighty eight (88) questionnaire administered to the above named bank staff, forty nine (49) were returned while thirty nine (39) were not due to non-challenged attitude demonstrated by the bank staff. 
From the avalanched of informed research, out of 49 respondents of the bank staff, 33 respondent were in affirmation that government policies would help in achieving an effective cashless society. So, it would therefore be inferred that government policies will help in achieving cashless society.

From the avalanche of informed research, out of 49 respondent of the bank staff, 36 respondents were in affirmation that effective application of cashless banking and electronic money would help in solving the problems associated with the use of cash. Therefore, it would be established that electronic money will help solve the problem associated with the use of cash; such of which are; cash related crimes, circulation of money outside the financial institution, influx of bank users in view to access their credit.

\section{Results/ Findings}

The major findings of the study were as follows:-

For e- banking to has an effective application in Nigeria, the regulating agencies must set a beddy eye on the movement of the real variables. The relative weakness of the regulators to place a lid on the movement of real variables is suggested in the Palley (2001) and Griffith (2004) where it is maintained that the tendency for e-money to substitute demand deposits may stifle the ability of the Central Bank to control money supply.

It is worthy of note that if the one of the primary purposes for which the cashless banking paradigm is introduced, which is to increase vault cash by discouraging the volume of quasi-money and cash in circulation are not achieved there may be an adverse impact of informal income growth on money supply.

On the foregoing electric banking has been adopted to a large extent in the Nigerian banking industry. It has affected deposits taking, cash withdrawals, money transfers, loan administration; the provision of banking services in several ways, these include quick data processing and retrieval of information increased customers satisfaction, quick customer service delivery and production of accurate and reliable information, faster access to capital, reduced revenue leakage and reduced cash handling costs.

In order words, the credit creation process which operates via the multiplication of deposits can be boosted to the extent to that e-money replaces time deposits and the extent to which demand deposits are substitute for e-money.

According to S. M. Nzotta (2004), the adoption of E-banking has greatly transformed the economy in the general sense of it and has enhanced the overall delivering of bank services. Given the perceived importance of E- banking, a study to evolve its implications on the delivery of banks services in Nigeria is considered imperative so as to gain more insight into its contribution to the economy and its effects.

With the Nigerian banking industry still smarting from the global economic meltdown few years ago and the insolvency, failures and mismanagement that resulted in the recent Mergers and Acquisitions (M\&As), the sector needs tighter control that will engender customer satisfaction and spur economic growth But this makes special precautions economically appealing and expedient. We are, however, concerned that while this cashless policy has its noble intentions with the ultimate aim of growing our economy and encouraging the emergence of e-payment across the country, the groundwork for the take off of the system has not been sufficiently done. It is one thing to borrow a good idea, but the success of that idea must take into cognizance the peculiar economic environment of the country. While some banks have been successfully carrying out transaction that are cashless some organisations and individuals still resort to carrying cash with the high risk involved. The apex bank has done a lot in placing restrictions in the movement of cash, and heavy sanctions on defaulters, there is still need for the general public to be educated so as to handle transactions properly.

\section{Conclusion And Suggestions}

Our main conclusions are that the central bank will lose its traditional instruments of monetary policy, Open market operations and advances to banks will become ineffective as instruments to control the interest rate and the money stock. We argue that this leads to two possible avenues for the future role of the central bank. In the first one the central bank becomes dependent on the treasury, both as a means to obtain revenues and as a way of maintaining some effectiveness of its traditional monetary policy instruments. Another avenue consists of strengthening the supervisory role of the monetary authority. This strengthening would include the quality control of the loan portfolios of the money issuing institutions as a way of ensuring market stability and to avoid bank runs. Simultaneously, supervision would allow the central bank to impose reserve requirements and to influence the money supply.

Cashless banking and electronic money are rather sophisticated means of solving the problems associated with the use of cash but as a sophisticated tool, it requires great planning in its application and this is due to the archaic socio-economic, political and financial structures of developing countries like Nigeria.

Hence care must be taken to ensure that e-money does not compete with demand deposit which still from the basis for credit creation in most developing economies like Nigeria and e-money must to a significant extent replace time deposits. This achievement depends largely on the measures being put in place to ensure that 
most of the informal sector-who constitutes a larger section of the economy holding time deposits - is made to patronize the use of e-money.

\section{References}

[1]. Adebiyi, D.A. (2003), “Accounting Process in a Computerized Environment” ICAN Students' Journal, April - June.

[2]. Aikorogie, K. (1998), "The Relevance of IT for Effective Bank Management". The Financier, A Publication of NABAFs, UNEC.

[3]. Akaubi, T.O. (1998), “The Cost and Benefit of Computer in Banking” Edited by Adewunmi and Akinlade, Lagos Landmark Publications.

[4]. Awad, M.E. (1970), “Automatic Data Processing; Principles and Procedures” New Jersey, Prentice Hall Inc.

[5]. Baxter, E.F. et al (1977), "Retail Banking in the Electronic Age" Monte Clair, New Jersey. Allowell Osmun and Co. Publishers Inc.

[6]. Baxter, W. (1983) "Bank Interchange of Transactional Paper: Legal and Economic Perspectives," Journal of Law and Economics, 26: $541-588$

[7]. Bergtt, J. Hann and J. Strum (2006), Does Money Matter in the ECB Strategy? Working Paper. Brito, Dagobert L. and Peter R. Hartley (1995) "Consumer Rationality and Credit Cards,"Journal of Political Economy, 103: 400-433.

[8]. Brown (1997), "Leaked National Bank Memo Confirms Pilot Version of Mondex Broken", Computer World News Wire. Sourced from (http://insight.mcmaster.ca/ora/efe/pages/media/nz-computerworld.12 Feb.2013).

[9]. Calder, Lendol (1999) Financing the American Dream: A Cultural History of Consumer Credit. Princeton University Press: Princeton, NJ.

[10]. Carow, Kenneth A. and Michael E. Staten (1999) "Debit, Credit, or Cash: Survey Evidence on Gasoline Purchases," Journal of Economics and Business 1999; 51:409- 421.

[11]. Castronova, Edward and Paul Hagstrom (2004) "The Demand for Credit Cards: Evidence from the Survey of Consumer Finances," Economic Inquiry, 42: 304-18.

[12]. Calder, Lendol (1999) Financing the American Dream: A Cultural History of Consumer Credit. Princeton University Press: Princeton, NJ.

[13]. Carow, Kenneth A. and Michael E. Staten (1999) "Debit, Credit, or Cash: Survey Evidence on Gasoline Purchases," Journal of Economics and Business 1999; 51:409-421.

[14]. Castronova, Edward and Paul Hagstrom (2004) "The Demand for Credit Cards: Evidence from the Survey of Consumer Finances," Economic Inquiry, 42: 304-18.

[15]. CBN (2011), Questions and Answers on the CBN Policy on Cash Withdrawal/Lodgment Limit. Sourced from: http://www.Cenbank .org/out/2011/press release/gvd/Revised \% 20 QnA.

[16]. Financial Action Task Force (2010), Money Laundering Using New Payment Methods. Sourced from: www.Fat F-gafio.org/datapecd/4/56/46705859 pdf. Chakravorti, Sujit (2002) "Theory of Credit Card Networks: A Survey of the Literature," Review of Network Economics, 2: 50-68.

[17]. Coopers \& Lybrand (1995). "Survey of Retail Merchants to Determine Costs of Payment Acceptance," Prepared for Visa USA.

[18]. Evans, David S. (2003) “The Antitrust Economics of Multi-Sided Platform Markets," Yale Journal on Regulation, $20: 325-381$.

[19]. Evans, David S. and Richard Schmalensee (2005) Paying with Plastic: The Digital Revolution in Buying and Borrowing. MIT Press: Cambridge, MA. Forthcoming. Food Marketing Institute (1998) A Retailer's Guide to Electronic Payment Systems Costs. Food Marketing Institute: Washington, D.C. Garcia-Swartz, Daniel D., Robert W. Hahn, and Anne Layne-Farrar (2006) "The Move Toward a Cashless Society: Calculating the Costs and Benefits," Review of NetworkEconomics, 5:175-198.

[20]. Godschalk and Krueger (2000), Why e-money Still Fails; Chances of e- money within a Competitive Payment Instrument Market. Paper Presented for the Third Berlin Internet Economics Workshop, Berlin.

[21]. Good (1997), Electronic Money; Working Paper 16, Federal Reserve Bank of Cleveland.

[22]. Good Friend and King (1997), The New Neoclassical Synthesis and the Role of Monetary Policy.

[23]. Goulder, Lawrence H. and Roberton C. Williams III (2003) "The Substantial Bias from Ignoring General Equilibrium Effects in Estimating Excess Burden, and a Practical Solution," Journal of Political Economy, 111: 898-927.

[24]. Griffith (2004), Electronic Money and Monetary Policy, South Western Economic Processing. Sourced from: http://www.thomas palley.com/docs/articles/macro theory/e-moneyrevolution pdf.

[25]. Humphrey, David B., Göran Bergendahl, Ted Lindblom, and Magnus Willesson (2003)

[26]. "What Does It Cost to Make a Payment?” Review of Network Economics, June 2003,159-174.

[27]. Humphrey, David B. and Allen N. Berger (1990) "Market Failure and Resource Use Economic Incentives to Use Different Payment Instruments," in David B. Humphrey (ed.),

[28]. The U.S. Payment System: Efficiency, Risk and the Role of the Federal Reserve. KluwerAcademic Publishers: Boston, MA.

[29]. Humphrey, David B., Lawrence B.Pulley, and Jukka M. Vesala (1996) "Cash, Paper, and Electronic Payments: A Cross-Country Analysis," Journal of Money, Credit and Banking,28: 914-939.

[30]. Klee, Elizabeth (2004) "Paper or Plastic: The Effect of Time on Check and Debit Card Use at Grocery Stores," SSRN Working Paper, http://ssrn.com/abstract=687159

[31]. Lacker, Jeffrey M. (1993) "Should We Subsidize the Use of Currency?” Federal Reserve Bank of Richmond Economic Quarterly, 79: 47-73.

[32]. Nafziger (2006), Economic Development; Fourth Edition Cambridge University Press. The Edinburgh Building, Cambridge Cb2 $2 \mathrm{~m} \mathrm{Uk}$

Table 1: How the questionnaire was distributed

\begin{tabular}{|l|c|c|c|}
\hline BANKS & $\begin{array}{c}\text { NUMBER OF } \\
\text { QUESTIONNAIRE } \\
\text { DISTRIBUTED }\end{array}$ & $\begin{array}{c}\text { NUMBER OF } \\
\text { QUESTIONNAIRE } \\
\text { RETURNED }\end{array}$ & PERCENTAGE (\%) \\
\hline ACCESS & 9 & 7 & \\
\hline UBA & 12 & 7 & \\
\hline ZENITH & 6 & 3 & \\
\hline DIAMOND & 4 & 2 & \\
\hline EEYSTONE & 4 & 2 & \\
\hline FINBANK & 6 & 3 & \\
\hline
\end{tabular}


A Critical Analysis of Cashless Banking Policy in Nigeria.

\begin{tabular}{|l|c|c|c|}
\hline WEMA & 3 & 3 & \\
\hline GTB & 4 & 4 & \\
\hline FCMB & 4 & 2 & \\
\hline STANBIC IBTC & 4 & 2 & \\
\hline FIDELITY & 5 & 2 & \\
\hline FIRST BANK & 12 & 5 & \\
\hline UNION BANK & 12 & 5 & \\
\hline 14 & 88 & 49 & \\
\hline
\end{tabular}

Source: Authors Field Survey (2012).

Table 2: Will Government Policies on the Banking Industry Help to Achieved an Effective Cashless Society?

\begin{tabular}{|c|c|c|c|c|}
\hline & \multicolumn{3}{|c|}{ RESPONSES } & \multirow[b]{2}{*}{ TOTAL } \\
\hline BANKS & YES & NO & INDIFFERENT & \\
\hline ACCESS & 5 & 2 & - & 7 \\
\hline UBA & 4 & 3 & - & 7 \\
\hline FINBANK & 2 & - & - & 2 \\
\hline FIRST BANK & 3 & 2 & - & 5 \\
\hline UNION BANK & 4 & 1 & - & 5 \\
\hline GTB & 3 & 1 & - & 4 \\
\hline WEMA & 1 & 2 & - & 3 \\
\hline DIAMOND & 1 & 1 & - & 2 \\
\hline ECOBANK & 1 & 2 & - & 3 \\
\hline FCMB & 1 & 1 & - & 2 \\
\hline STANBIC ITBC & 2 & - & - & 2 \\
\hline KEYSTONE & 2 & - & - & 2 \\
\hline FIDELITY & 2 & - & - & 2 \\
\hline ZENITH & 2 & 1 & - & 3 \\
\hline & 33 & 16 & - & 49 \\
\hline
\end{tabular}

Source: Authors Computation (2012).

Table 3: Will the Application of Effective Cashless Banking and Electronic Money help in Solving the Problems Associated with the Use of Cash?

\begin{tabular}{|c|c|c|c|c|}
\hline & \multicolumn{3}{|c|}{ RESPONSES } & \multirow[b]{2}{*}{ TOTAL } \\
\hline BANKS & YES & NO & INDIFFERENT & \\
\hline ACCESS & 5 & 1 & 1 & 7 \\
\hline UBA & 4 & 1 & 2 & 7 \\
\hline FINBANK & 2 & - & - & 2 \\
\hline FIRST BANK & 4 & 1 & - & 5 \\
\hline UNION BANK & 5 & - & - & 5 \\
\hline GTB & 2 & 2 & - & 4 \\
\hline WEMA & 3 & - & - & 3 \\
\hline DIAMOND & 2 & - & - & 2 \\
\hline ECOBANK & 2 & 1 & - & 3 \\
\hline FCMB & 1 & 1 & - & 2 \\
\hline STANBIC ITBC & 2 & - & - & 2 \\
\hline KEYSTONE & 2 & - & - & 2 \\
\hline FIDELITY & - & 1 & 1 & 2 \\
\hline \multirow[t]{2}{*}{ ZENITH } & 2 & 1 & - & 3 \\
\hline & 36 & 9 & 4 & 49 \\
\hline
\end{tabular}

Source: Authors Computation (2012). 